XX. Heredity in six families of Papilio dardanus, Brown, Subspecies cenea, Stoll., bred at Durban, by Mr. G. F. Leigh, F.E.S. By Edward B. Poulton, D.Sc., M.A., LL.D. (Princeton), F.R.S., etc., Hope Professor of Zoology in the University of Oxford, Fellow of Jesus College, Oxford.

\title{
Plates XXIII and XXIV.
}

[Read June 3rd, 1908.]

Between September 1902 and March 1905 Mr. G. F. Leigh has bred families twice from each of the three mimetic female forms of the south-eastern subspecies of Papilio dardanus, Brown. The whole of the resulting material, with the exception of a portion of the first family, exists in the Hope Department, and it is of sufficient magnitude to justify a general account and to support certain important conclusions.

The first section of this paper will deal with the hereditary relationship of the several female forms. Evidence will be produced in favour of the conclusion that their proportion, at any rate in certain localities, is due in part to the proportion and in part to the relative conspicuousness of the Danaine models.

The second section will deal with the hereditary relationship in certain elements of the mimetic pattern. The attempt will be made to show the manner in which the details of the mimetic forms have been brought to resemble those of their models.

The unfortunate clerical errors in Professor Weismann's recent use of this species as an example of mimicry ("The Evolution Theory," English transl., Lond., 1904, vol. i, Pl. I) render it very desirable that the female forms should be again represented in coloured figures, together with their models. A full correction of the mistakes here referred to will be found in the writer's "Essays on Evolution," Oxford, 1908, pp. 375, 376, from which the following passage is quoted:- " Professor Weismann's prolific labours and great discoveries give an authority and influence to these unlucky copyist's errors, and therefore it is of the utmost importance to set them right in detail" (p. $375)$.

TRANS. ENT. SOC. LOND. 1908. - PART III. (DEC.) 
Very beautiful drawings of both surfaces of the hippocoon, F., parent of Family 4 and of an example of each mimetic form among its female offspring, as well as of their Danaine models, have been made by my friend Mrs. P. P. Whelpley. I desire to express my warm thanks to her for this beautiful work and the great care and skill required for its production. Mr. Abbott $\mathrm{H}$. Thayer, who saw the painting, assured me that the colouring was as perfect as it could be made. Messrs. André \& Sleigh have devoted great pains to Plate XXIII, containing a reproduction of the painting on the reduced scale which was unfortunately necessary. The Danaine models were all captured by my kind friend Mr. G. A. K. Marshall within a few miles of the localities where Mr. Leigh took the parents of these families.

Hereditary influence upon the details of pattern is especially well studied in Family 5 , of which all the significant members are reproduced in half tone on Plate XXIV, prepared by Messrs. Witherby from a beautiful photograph by Mr. Alfred Robinson of the Oxford University Museum.

\section{SECTION I}

Hereditary relationship of the female forms of P. Dardanus, subsp. Cenea, at Durban.

The one striking result which is evident on a glance at the table on p. 429 , is the predominance of the cenea female form in the offspring of each of these families. Whether the parent be cenea itself or the very different hippocoon or trophonius, cenea is invariably most numerously represented in the offspring. In two cases no other form appeared, and in two more only a single example of another form.

The results obtained by breeding from cenea are very concordant-in both cases a vast preponderance of cenea, and in one case 1, in another 3 examples of hippocoon. When trophonius was the parent only very small numbers of offspring were reared, but the results are concordant:-only cenea when the numbers are very small; cenea with a single trophonius when they are larger. The results yielded by hippocoon were, on the other hand, astonishingly different:-in one case only cenea, in the other the highly remarkable Family 4 with a larger pro- 
Heredity in six families of Papilio dardanus. 429

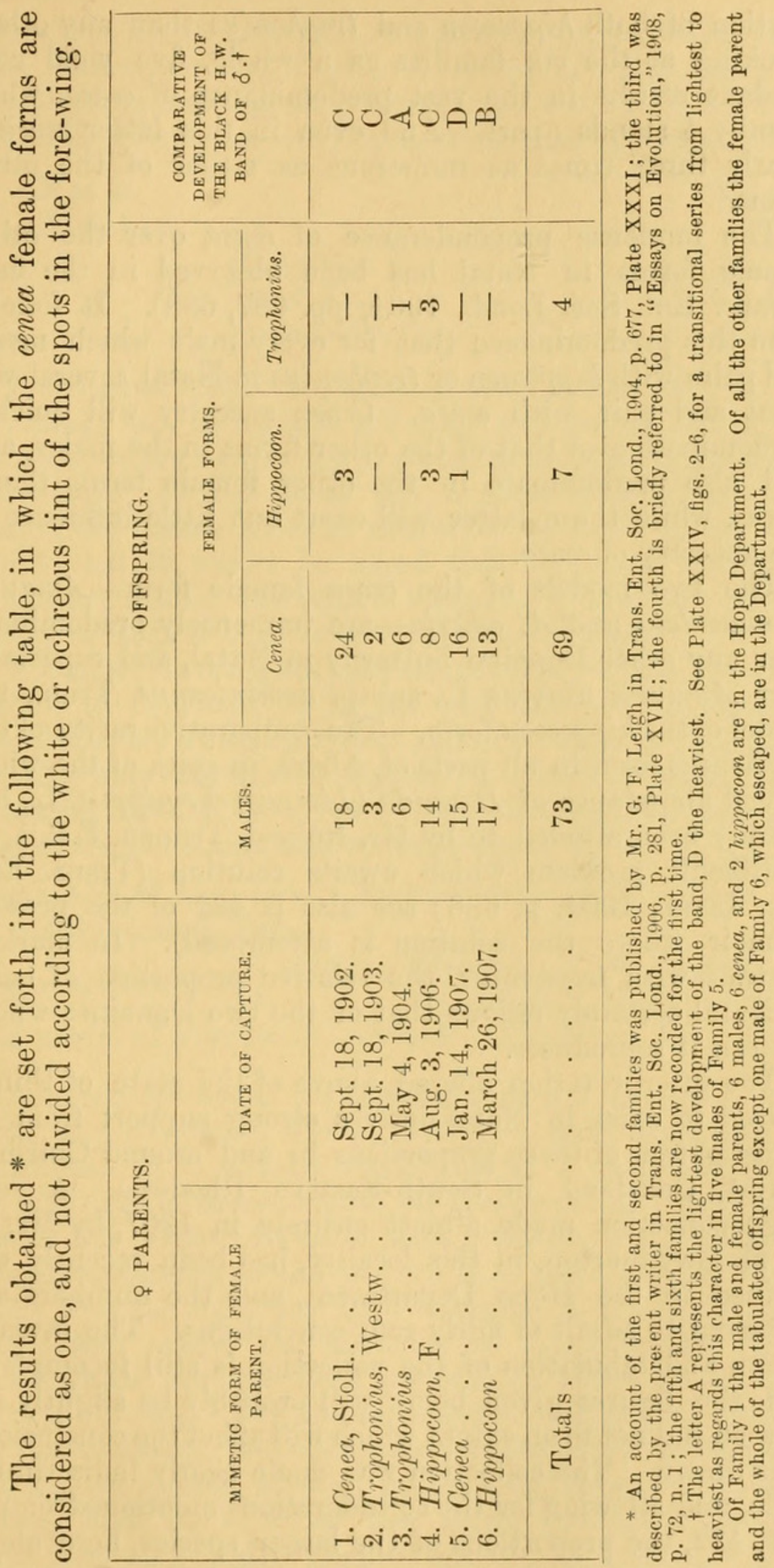


portion of both hippocoon and trophonius than any other. Looking at the six families as a whole, five yield concordant results in the vast predominance of cenea, while Family 4 stands apart. And even in this latter cenea is nearly three times as numerous as either of the other forms.

The immense preponderance of cenea over the other female forms in Natal has been observed in the field (Trans. Ent. Soc. Lond., 1904, pp. 687, 688). It follows from this predominance that for every male which meets and pairs with hippocoon or trophonius in Natal, several will meet and pair with cenea. Cenea ancestry will quickly predominate over that of the other forms in the males, and will also predominate in the other female forms themselves, while these latter will exert but little influence in the ancestry of cenea.

The two models of the cenea female form-Amauris albimaculata and $A$. echeria - are immensely predominant over any other Danaine butterfly in Natal, and especially over Amauris niavius, L., subsp. dominicanus, Trim., the model of the hippocoon form. The comparative rarity of the trophonius form in all parts of Africa, in spite of the widespread abundance of Danaida (Limnas) chrysippus, L., has already been alluded to by Mr. Roland Trimen, F.R.S., as a difficult problem which awaits solution (Trans. Ent. Soc. Lond., 1904, p. 688: see also p. 432 of the present memoir where the solution is attempted). In marked contrast with trophonius, the relative proportion of cenea in Natal certainly follows that of the two Danaines whose pattern it reproduces.

The interpretation offered above of the state of things proved to exist in Natal derives strong support from an investigation of these proportions in and around Chirinda Forest, Gazaland, in South-Eastern Rhodesia. A very large collection made, almost entirely in 1907, by Mr. C. F. M. Swynnerton, in this locality, has been recently examined in the Hope Department, and the numbers are sufficient to admit of fairly safe conclusions. The investigation and tabulation of the collection is still incomplete, and the figures given below will probably be slightly increased, but not to an extent which will affect the conclusions here drawn. The collection was made nearly indiscriminately, and allowing for the considerations mentioned on pp. 431,432 , the proportions of the larger species, here alone 
taken into account, may be accepted as approximately correct. The numbers of Papilio dardanus (of which nearly all the Chirinda males possess the heavy black hind-wing band of the E. subspecies, tibullus, Kirby, are as follows :-

Males

Females

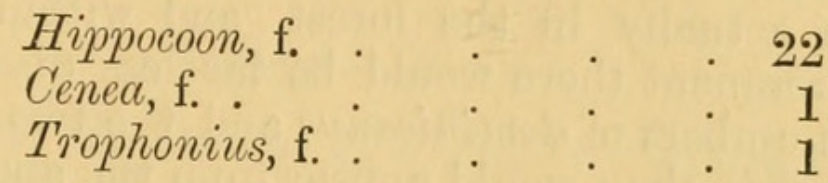

Trophonius, mimicking $D$. chrysippus, is thus rare, as it is in Natal; but, as regards the other two female forms, the proportions are reversed, hippocoon being predominant and cenea rare. It will be of the highest interest to breed from these female forms at Chirinda. There can be little doubt that it would be found that hippocoon here predominates among the female offspring of a female parent of any form, just as cenea predominates in Natal.

When we investigate the proportions of the Danaine models at Chirinda we do not find that predominance of the black and white species of Amauris which is suggested by the numbers of the hippocoon mimetic form. The following results have been so far obtained, but a small part of the collection still remains unexamined :-

The model of hippocoon-Amauris niavius, L., subsp. dominicanus, Trim.

The models of cenea $\{$ Amauris lobengula, E. M. Sharpe 196 The model of trophonius-Danaida chrysippus, L. $\quad .109$

Amauris lobengula represents, and is probably a local form of, A. echeria, Boisd., which is still unknown at Chirinda. It is equally serviceable as a model for cenea. In addition to dominicanus, 22 specimens of the smaller black and white Amauris ochlea, Boisd., were counted; but the difference in the pattern is so great that it is unlikely that the influence upon hippocoon is greatly affected. Neglecting ochlea, the numbers of the Danaine model of hippocoon are less than one-fifth of those of the two models of cenea. Yet this small proportion is accompanied by the immense preponderance of hippocoon revealed in the figures quoted above. As bearing upon these interesting and, in view of the effect produced, remarkable proportions, Mr. Swynnerton tells me that lobengula 
and albimaculata are so excessively abundant that his native boy would get tired of catching them, whereas he would secure every specimen of dominicanus that came in his way. But on the other hand, as Mr. G. A. K. Marshall and Mr. Swynnerton have both pointed out to me, the females of dardanus probably spend a great deal of their time actually in the forest, and within that particular environment there would be far less discrepancy between the numbers of dominicanus and the two other species of Amauris, than would appear from the above tabular statement. Nevertheless, it has been already shown that echeria and albimaculata are exceedingly effective models for dardanus in Natal, and the same is true of the south coast of Cape Colony. Making every allowance therefore for the above considerations, I am driven to conclude that dominicanus possesses some special advantages as a model over the other two species, which may compensate for a numerical inferiority. These advantages may be conferred by the far greater conspicuousness which renders it visible at a much greater distance than either lobengula or albimaculata.* It must. be remembered furthermore that, although so much less numerous than the other two, dominicanus is quite a common butterfly at Chirinda, whereas in Natal it is generally rare, and often altogether unseen for long periods in many localities where Papilio dardanus is found.

It is interesting to compare Papilio echerioides, Trim., with $P$.dardanus. The former is also common at Chirinda, 39 males and 17 females having been so far counted. The females, as is well known, are beautifnl mimics on the upper surface of Amauris echeria (or lobengula) and albimaculata. For this Papilio the latter are evidently very effective models, but for dardanus, with another form, mimicking the black and white Danaines, their influence in spite of preponderant numbers is entirely subordinate.

The relative rarity of the trophonius form in the west and east, as well as the south of Africa, in spite of the general abundance and wide range of its model, has often been remarked upon (see p. 430; also Trans. Ent. Soc. Lond., 1904, p. 688). In this case the facts are probably to be explained by difference of habitat, chrysippus being an open

* It would also be very interesting to investigate the relative efficiency of the special means of protection possessed by these three Danainx. 
country and woodland species, while dardanus is a forest insect. Model and mimic would ordinarily only meet at the lines of contact between their respective types of country. Both Mr. Marshall and Mr. Swynnerton to whom I have mentioned this hypothesis agree that it probably accounts for the fact.

\section{SECTION II}

Description of Families 4, 5 and 6 : Hereditary TENDENCIES IN THE DETAILS OF THE MIMETIC PATTERNS.

The fore-wing spots of the cenea form.

Before describing the details of these three families now recorded for the first time, it will be convenient to enumerate the spots of the fore-wing of the cenea form, of which the five largest were described in 1904 (Trans. Ent. Soc. Lond., 1904, pp. 680, 681). The terminology then suggested will now be extended to include all the spots of the fore-wing:-

A. Spots arranged in a curve in part below and in part round the distal end of the cell.

(1) The principal spot (oval): between veins 2 and 3 .

(2) An elongated spot: between veins 4 and 5 .

(2a) Rarely present (e. g. in Plate XXIV, figs. 20, 21): between veins 5 and 6 .

(3) Oval, but broader than (2): between veins 6 and 7 .

(4) The blunt distal end is commonly emarginate: between veins 8 and 9 .

(4a) Occasionally present (e.g. in Plate XXIV, figs. 14-19): between veins 9 and 10 .

B. The spot within the cell.

(5) An irregular spot, with the inner extremity often cut off as a separate minute spot (e. g. in Plate XXIV, figs. 1, 12, 13, 16, 17, \&c.).

C. The submarginal spots, of which four are usually present.

(a) At the anal angle; generally minute: between veins 1 and 2 .

( $\beta$ ) Generally larger: between veins 2 and 3 .

$(\gamma)$ Generally larger still: between veins 3 and 4 .

$(\delta)$ At the apical angle, generally largest: between veins 7 and 8 . 
The fourth Family :-

4. HIPPOCOON, ㅇ Parent (Plate XXIII, fig. 1).

Captured August 3, 1906 . Laid 32 eggs, August 4-6. Hatched August 10-12.

\begin{tabular}{|c|c|c|c|}
\hline \multicolumn{4}{|c|}{ OFFSPRING. } \\
\hline & DATE OF PUPATION. & DATE OF EMERGENCE. & SEX AND $q$ FORM. \\
\hline & 1906 & 1906 & \\
\hline 1. & September 8 & September 19 & ô \\
\hline 2. & No date. & September 21 & \\
\hline 3. & No date. & September 22 & $\begin{array}{l}\text { ocenea (chief spot } \\
\text { in fore-wing pale } \\
\text { ochreous). }\end{array}$ \\
\hline 4. & No date. & September 23 & \\
\hline 5. & No date. & September 23 & o \\
\hline 6. & September 13 & September 23 & \\
\hline 7. & September 13 & September 24 & q trophonius. \\
\hline 8. & September 14 & September 26 & \\
\hline 9. & September 14 & September 26 & \\
\hline 10. & September 14 & September 30 & $\begin{array}{l}+ \text { cenea (chief spot } \\
\text { in fore-wing white. } \\
\text { Plate XXII, fig. } \\
4 \mathrm{~A} \text { ). }\end{array}$ \\
\hline 11. & September 16 & September 30 & q cenea (spot white). \\
\hline 12. & September 18 & October 1 & \\
\hline 13. & September 18 & October 1 & $\begin{array}{l}\text { o cenea (spot ochre- } \\
\text { ous). }\end{array}$ \\
\hline 14. & September 20 & October 2 & \\
\hline 15. & September 21 & October 6 & o cenea (spot white). \\
\hline 16. & September 21 & October 7 & $\begin{array}{l}\text { trophonius (Plate } \\
\text { XXIII, fig. } 3 \mathrm{~A}) \text {. }\end{array}$ \\
\hline 17. & September 23 & October 9 & $\begin{array}{l}\text { cenea (spot ochre- } \\
\text { ous, as also is the } \\
\text { spot within the } \\
\text { fore-wing cell). }\end{array}$ \\
\hline 18. & September 23 & October 10 & q hippocoon. \\
\hline 19. & September 24 & October 13 & o trophonius. \\
\hline 20. & September 24 & October 15 & $\begin{array}{l}\text { o hippocoon (Plate } \\
\text { XXIII, fig. 2A). }\end{array}$ \\
\hline 21. & September 23 & October 15 & $\begin{array}{l}\text { q cenea (spot ochre- } \\
\text { ous). }\end{array}$ \\
\hline 22. & September 25 & October 18 & o \\
\hline 23. & September 26 & October 18 & ô. \\
\hline 24. & September 26 & October 19 & q hippocoon. \\
\hline 25. & September 27 & October 20 & \\
\hline 26. & September 30 & October 21 & o \\
\hline 27. & October 2 & October 23 & \\
\hline 28. & No date. & October 24 & $\begin{array}{l}\text { o cenea (spot ochre- } \\
\text { ous. Plate XXIII, } \\
\text { fig. } 5 \mathrm{~A} \text { ). }\end{array}$ \\
\hline
\end{tabular}


These results are the most remarkable hitherto attained by Mr. G. F. Leigh, all the forms being represented in considerable proportions, and the predominance of cened being far less marked than in any other family.

The hippocoon parent. - A glance at fig. 1 on Plate XXIII will show that the parent is a normal hippocoon form with spot (5) undivided.

The fourteen male offspring.-The heaviness of the hindwing band is about as in Families 1 and 2, viz. next to the darkest, Family 5, but separated from it by a considerable interval.

The three hippocoon offspring.-The individual represented in Plate XXIII, fig $2 \mathrm{~A}$, is the only one with spot (5) in the cell of the fore-wing divided. In the other two the chief white marking is smaller, suggesting the appearance of forms from the West Coast (merope).

The three trophonius offspring.-In all three examples a pale fulvous tint spreads from the nervules crossing the subapical white bar, and in one example also overspreads the outer half of spot (5). The lens shows that this tint is due to fulvous scales scattered over the white areas, and thickly crowded along the nervules.

Although the upper surface pattern of trophonius at first sight appears to be nothing more than hippocoon with the white of the chief marking replaced by fulvous-a view adopted by the present writer in Trans. Ent. Soc. Lond., 1906, p. 290-in certain special points it has diverged in the direction of its particular model, chrysippus. In the fore-wing the fulvous area invades or overspreads the black ground-colour towards the base of the cell. In the hind-wing the outer border of the fulvous area projects into the black margin between the nervules, forming a scalloped junction which, as in D. chrysippus itself, is more strongly marked in the costal half of the wings. The fulvous area is also more sharply marked off from the black margin than in the hippocoon form. These points of distinction are small and developed very variably. They are better seen when Fig. $3 \mathrm{~A}$ is compared with Fig. $2 \mathrm{~A}$ than when it is compared with Fig. 1.

Spot (5) is undivided in the three trophonius offspring.

The eight cenea offspring. - It has already been shown in the tabular statement that three of these individuals have the chief spot (1) of the fore-wing white (e.g. as in the individual shown on Plate XXIII, fig. 4A), while in

TRANS. ENT. SOC. LOND. 1908.—PART III. (DEC.) 29 
five it is pale ochreous (as in Fig. $5 \mathrm{~A}$ ). In that one specimen out of the five in which spot (1) is the palest, the spot within the cell (5) is of a pronounced ochreous tint. Spot (5) is divided on the left side of one out of the three individuals with the chief spot white: among the five with the chief spot pale ochreous it is divided in two, and on the left side in a third individual. Spot $(4 a)$ is shown on the upper but not on the under surface of the individual represented on Plate XXIII, fig. 5A. It can only be made out with a lens and on one side only in a single specimen out of seven remaining cenea. Excluding minute traces revealed by the lens, spot $(2 \alpha)$ is wanting from the upper surface of all examples, but is present on the under surface of one specimen out of the three and with the chief spot white, and of two out of the five others. Other characteristics of these eight specimens are considered in the following sub-section :-

Probable hereditary effects of the hippocoon form upon offspring of other forms.

In all the three cenea offspring with the chief spot (1) in the fore-wing white, the costal third of the ochreous basal patch of the hind-wing becomes white, as is shown in Plate XXIII, fig. $4 \mathrm{~A}$. The ochreous tint of the remainder of the patch is also unusually pale. In the two individuals in which this change towards the costal border of the hind-wing is most marked, the chief spot of the fore-wing spreads outwards and downwards beyond the first median nervule (Fig. 4A). In all three examples there is a small ochreous linear mark towards the base of the inner margin of the fore-wing, thus very slightly extending the pattern of the hind-wing on to the fore.

In all the five cenea offspring with the chief spot (1) of the fore-wing pale ochreous, this linear mark is also present (Fig. 5A), but the extension of the chief spot is only found in two of them.

A whiteness towards the costal margin of the hind-wing upper surface, like that of three cenea females, is found in two of the males and on the left side of a third. There is also a paling of the yellow on one side in the cell of the fore-wing of a few males which has more of an abnormal appearance. The paling of the hind-wing, however, corresponds in position with that of the three cenea, and is probably due to the same cause. 
The fifth Family:-

5. CENEA, \& Parent (Plate XXIV, fig. 1).

Captured January 14, 1907. Laid 42 eggs, January 15 and 16.

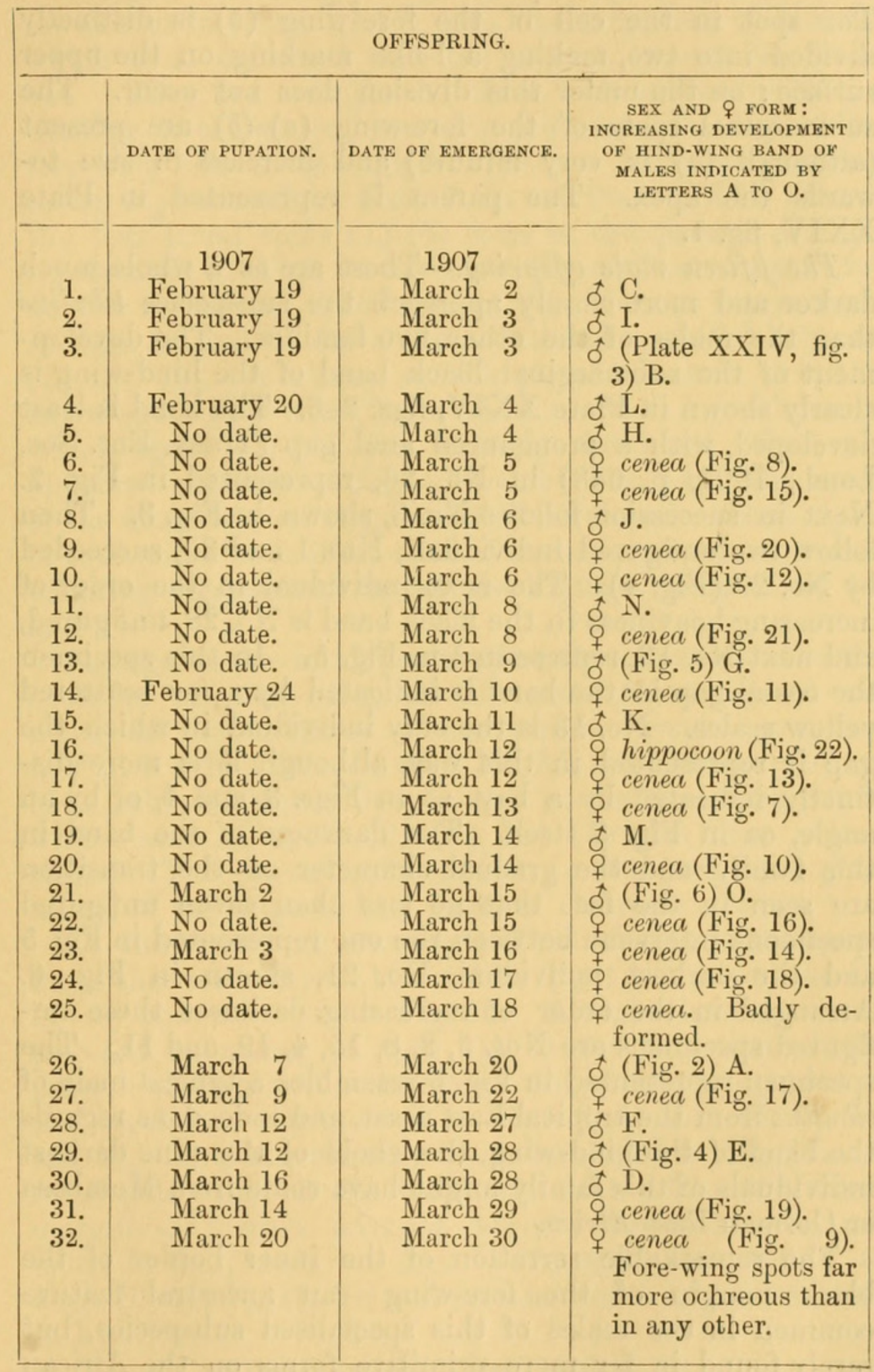


The cenea parent.-The spots round the end of the cell (1)-(4) are large and well developed, but neither $(2 a)$ nor (4a) is present. The chief spot (1) is very pale ochreous, with a minute trace of a downward extension, as if slightly in the direction of the pattern of hippocoon and trophonius. The spot in the cell of the fore-wing (5) is distinctly divided into two, making a !-like marking on the upper surface: on the under this division does not occur. The submarginal spots of the fore-wing $(a)-(\delta)$ are present (although $(a)$ is very minute) and increase in size towards the apex. The parent is represented in Plate XXIV, fig. 1.

The fifteen male offspring.-These are as a whole much darker and more closely approach the subspecies tibullus than the males of the other five families. The development of the submarginal black band of the hind-wing is clearly shown in Plate XXIV, figs. 2-6. The band is least developed, with a pronounced anal gap (Trans. Ent. Soc. Lond., 1904, p. 683) in No. 26, represented in Fig. 2. Next in succession follows No. 3, shown in Fig. 3. Then follow two unfigured individuals, Nos. 1 and 30, succeeded by No. 29 (Fig. 4). The next individual in the order of increasing heaviness in the black band is No. 28, unfigured, and next No. 13, represented in Fig. 5. In this specimen the costal gap in the band is indicated by a few scattered yellow scales. No. 13 is the only individual in which the gap is represented in this way, although it is more distinctly indicated by a bay, as in Figs. 3 and 4 , or by an angle, as in Fig. 5 itself. The darkness of the band in this family and the gradual character of the transition are seen in the fact that no less than seven unfigured specimens intervene between the one represented in Fig. 5 and the darkest individual, No. 21, shown in Fig. 6. Arranged in the order of increasing darkness these unfigured specimens are Nos. 5, 2, 8, 15, 4, 19, and 11. The specimen represented in Fig. 6 resembles a typical male of tibullus from the tropical East coast, and indeed, as regards the band of the hind-wing, the whole of the nine darkest individuals of this family might have come from Mombasa or German East Africa.

The remarkable serration of the inner border of the black margin of the fore-wing - an ancestral feature common in the males of this specialised subspecies, but rarely found in far more primitive forms on the African 
continent*-is well seen in Fig. 6, less characteristically in Fig. 2. Half of the unfigured specimens also exhibit the same feature, while the others resemble the condition represented in Figs. 3, 4, and 5.

The sixteen cenea offspring. - All the females of this form are shown in Plate XXIV, with the exception of No. 25 which is so deformed that the pattern cannot be made out. They are arranged in three sets according to the number of the white spots grouped round the end of the fore-wing cell on the upper surface. The seven specimens represented in Figs. 7-13 on Plate XXIV possess the four usual spots (1)-(4) seen in the parent; the six represented in Figs. 14-19 have the additional spot (4a) on the costal and inner side of (4): the two represented in Figs. 20 and 21 have the additional spot $(2 \alpha)$ between (2) and (3). A glance at the plate will show that the extra spots $(4 \alpha)$ and $(2 \alpha)$ tend to occur in individuals in which spots (1)-(4) are strongly developed, the only apparent exception being offered by Fig. 14. The spots of the fore-wing are large and well developed-about equal or even superior to those of the female parent-in the cenea offspring represented in all the Figures except $7,8,11$, and 14.

As regards the development of a pale ochreous tint in the spots of the fore-wing, all the cenea forms figured are nearly in the condition of the parent except that shown in Fig. 9. In this specimen, No. 32, spots (1) and (3) are of an ochreous tint as deep as that of the hind-wing patch, while parts of spots (2) (4) and (5) also bear yellow scales. The specimen is, in fact, in this respect a good mimic of the Cape Colony forms of Amauris echeria.

Of the remaining cenea, spot (1) is whitest in the specimens shown in Figs. 11 and 15. Spot (3) as well as (1) is very pale ochreous in Fig. 16. A slight downward and outward extension of spot (1) in the direction of the pattern of hippocoon is developed much as in the parent in the specimens represented in Figs. 9, 10, 11, 14, 17, 19, and 21. It is considerably more developed in Fig. 18. A small pale mark on the basal part of the fore-wing inner margin-a further advance towards hippocoon, etc., not found in the parent-is seen in the specimens shown in Figs. 10, 11, 14, 19, 21, and in a far more advanced state in Fig. 18.

* Trans. Ent. Soc, Lond,, 1906, p. 282. 
It is now necessary to describe, as briefly as possible, some of the chief features in the fore-wing pattern of each of the cenea forms :-

Fig. 7 (No. 18) : spot (5), divided in the parent, is here undivided : a distinct trace of $(4 \alpha)$ can be seen on the under surface. The marginal spots are much less developed than in the parent, $(\gamma)$ and $(\delta)$ being minute and the others wanting: below $(\delta)$ is wanting also. Part of the pupal case is still adhering behind the head.

Fig. 8 (No. 6) : (5) divided on right side, undivided below : very faint traces of $(4 \alpha)$ and $(2 \alpha)$ can be made out with a lens on the under surface. $(a)$ can be made out with a lens, $(\beta)$ minute, others small. All distinct below and $(\gamma)$ large.

Fig. 9 (No. 32) : (5) divided on upper surface only, but the outer portion is very minute especially on right side. The additional spots are unrepresented on under surface. $(a)-(\delta)$ well developed, $(a)$ and $(\delta)$ more so than in parent.

Fig. 10 (No. 20) : (5) undivided: under surface as in Fig. 9; marginal spots nearly as in Fig. 8. Below (a) minute on left side, $(\beta)$ and $(\gamma)$ large, $(\delta)$ absent.

Fig. 11 (No. 14) : (5) undivided: a small but distinct trace of $(2 a)$ below: marginal spots absent above: below $(\alpha)-(\gamma)$ small and $(\beta)$ barely visible on left side.

Fig. 12 (No. 10): (5) divided distinetly above and nearly divided below: $(4 a)$ distinct below and a trace can be identified with a lens above: $(2 \alpha)$ wanting below : (a) absent, $(\delta)$ minute, others normal as in parent. Below $(\delta)$ absent: others normal as in parent.

Fig. 13 (No. 17): (5) as in Fig. 12 but the lower spot is minute, especially on right side : $(2 a)$ distinct below and $(4 a)$ a trace : marginal spots as in Fig. 12 except that $(\delta)$ is large.

Fig. 14 (No. 23): (5) divided on left side, fused but constricted on right, below fused on both sides: $(4 a)$ small but quite distinct, larger below : $(\gamma)$ minute, all others absent, similar below except for a minute trace of $(\beta)$ on left side only.

Fig. 15 (No. 7): (5) divided, but not below, though traces of division are distinct: $(4 \alpha)$ as in Fig. 14 but rather larger: a trace of $(2 a)$ below: marginal spots much as in Fig. 13, but $(\beta)$ even more minute above, and $(a)$ absent above and below. 
Fig. 16 (No. 22): deformed: yellower spots in forewing than any except Fig. 9: (5) divided below as well as above: $(4 \alpha)$ as in Fig. 15: $(2 \alpha)$ in two patches below : submarginal spots similar to parent on both surfaces, except that $(a)$ is wanting above.

Fig. 17 (No. 27): (5) divided and the larger portion also nearly divided, so that the marking appears as three sub-equal spots: below the ordinary division holds and the other is indicated: $(4 a)$ as in Fig. 15 etc. and very distinct below: submarginal spots like parent but $(\alpha)(\beta)$ smaller and $(\gamma)(\delta)$ larger both above and below: $(\gamma)$ below larger than $(\delta)$.

Fig. 18 (No. 24) : (5) very large, undivided above and below: $(4 a)$ distinct above and below: no trace of $(2 \alpha)$ below : marginal spots very similar to Fig. 17 only (a) absent above and minute below. The rather marked transition to hippocoon shown in this specimen has been already pointed out (p. 439).

Fig. 19 (No. 31): much like Fig. 18 except that a very slight trace of $(2 a)$ appears below, especially distinct on left side: $(\delta)$ absent above and below, others normal on both surfaces, (a) being minute above as usual.

Fig. 20 (No. 9): fore-wings deformed, especially on right side: (5) divided on both surfaces: $(4 a)$ distinct below, especially on right side, absent above : (2a) small on left side, large below ; on right side invisible above (perhaps due to fold in wing); small below but evidently much concealed in fold: $(\gamma)$ and $(\delta)$ alone present above: below on left side (right much deformed) ( $\delta$ ) absent but other three normally developed.

Fig. 21 (No. 12): (5) divided above but not below : no $(4 a)$ on either surface: $(2 a)$ very large both above and below: $(a)$ and $(\beta)$ can only be identified by a lens, $(\gamma)$ and $(\delta)$ are well developed and sub-equal; below $(\delta)$ is minute on right side, absent on left, $(a)$ and $(\beta)$ normally developed and $(\gamma)$ large.

The single hippocoon offspring. - The pattern of this specimen is well shown in Plate XXIV, fig. 22.

Fig. 22 (No. 16): (5) divided above but not below: $(2 a)$ is much the largest spot in the subapical bar of hippocoon on both surfaces. ( $4 a$ ) is absent, for a linear 
white streak along the second subcostal does not appear to correspond with it: nor is this spot represented on the under surface. The submarginal spots are normal on the upper surface except for the absence of $(a)$, on the lower except for the absence of $(\delta)$.

\section{The sixth Family:-}

\section{HIPPOCOON, ㅇ Parent.}

Captured March 26, 1907. Laid ova March 27-8, and died on evening of March 28.

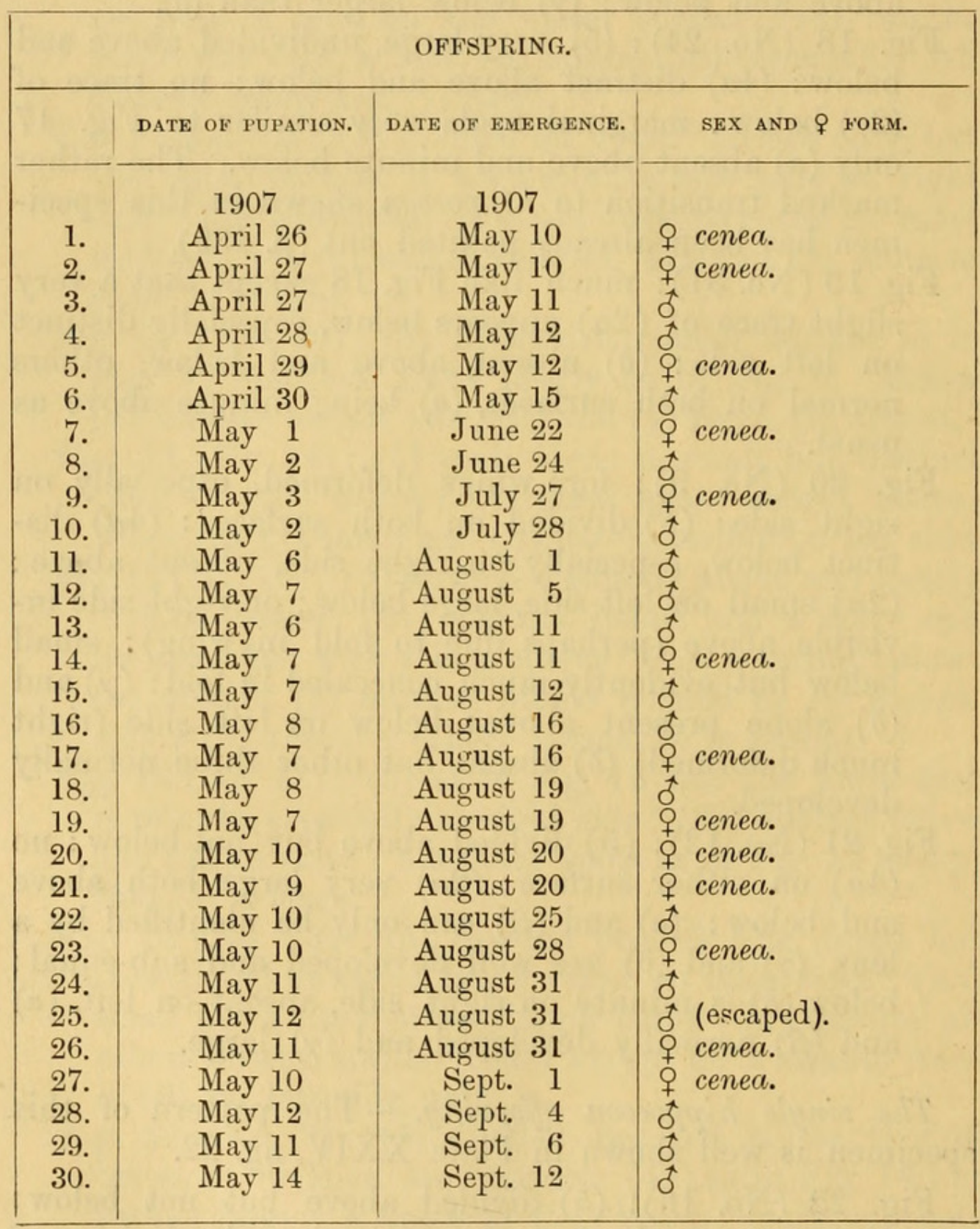

It is not necessary to describe this family in any detail ; 
as its interest lies in the exclusive predominance of cenea female forms and in the astonishing contrast afforded with Family 4, also bred from a hippocoon parent. It is of considerable interest, as Mr. G. F. Leigh pointed out to me, that the pupal condition of the great majority of examples was prolonged through the winter months, although a certain number emerged after the usual period.

The hippocoon parent.-The specimen is a normal example of this form with spot (5) undivided.

The seventeen male offspring.--The variable black marking: of the hind-wing was on the whole less heavily developed in the males than in those of any except Family 3.

The thirteen female offspring - entirely cenea forms.-All the thirteen specimens possess ochreous scales in spot (1), which however appears white to the naked eye in Nos. 23 and 26. Spot (1) is of a pronounced ochreous tint and (3) very faintly ochreous in Nos. 14, 17, 20 and 27. Spot (1) extends downwards and outwards, in the direction of the pattern of hippocoon, etc., in Nos. 14, 17, 19 and 20 and very slightly in No. 9. A slight ochreous linear mark near the basal end of the inner margin of the fore-wing also tending in the direction of hippocoon, etc., is seen in Nos. 1, 14, 17, 19, 20 and 27. Spot (5) is divided in Nos. 9,17 and, on the right side, 23 : it is nearly divided in No. 5 .

Relation between the male offspring in the six Families.The increasing heaviness of the black hind-wing band is shown by the letters $A-D$ in the table on p. 429. It must be borne in mind that there is a considerable interval between stages $\mathrm{C}$ and $\mathrm{D}$, but that the other intervals are small. In all six families the pronounced serration of the inner border of the fore-wing black margin is seen in a considerable proportion of the males, and quite as often in the more heavily marked as in the less heavily marked individuals. Indeed upon the whole it appeared to be slightly more characteristic of the latter.

Hereditary tendencies in the details of the mimetic pattern.-A comparison of the mimetic forms with one another in each family and with those of the other families indicates the ample nature of the variational material by which the mimetic pattern has been and could be again adjusted to the details of the patterns presented by the models. The condition of three elements in the pattern of the fore-wing upper surface of the cenea offspring, and of 
one in the hippocoon and trophonius offspring of the six families, is shown below in a tabular form. When the character is present on right or left side only it is counted as $\frac{1}{2}$, and if on one side of two individuals as 1 .

\begin{tabular}{|c|c|c|c|c|c|}
\hline 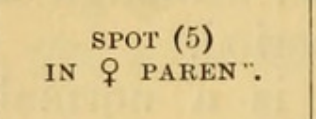 & $\begin{array}{l}\text { FEMALE OFFSPRING } \\
\text { IN CUNDITION FOR } \\
\text { STLDY. }\end{array}$ & $\begin{array}{l}\text { NUMBER } \\
\text { EX- } \\
\text { AMINED. }\end{array}$ & $\begin{array}{l}(5) \\
\text { DIVIDED } \\
\text { IN. }\end{array}$ & $\begin{array}{l}(4 a) \\
\text { PRESENT } \\
\text { IN. }\end{array}$ & $\begin{array}{l}(2 a) \\
\text { PRESENT } \\
\text { IN. }\end{array}$ \\
\hline \multirow{2}{*}{$\begin{array}{c}\text { Family } 1 . \\
\text { cenea }: \text { divided. }\end{array}$} & cenea & 6 & 1 & 0 & 0 \\
\hline & hippocoon & 2 & 1 & 一 & - \\
\hline $\begin{array}{l}\text { Family } 2 . \\
\text { trophonius: } \\
\text { divided. }\end{array}$ & cenea & 2 & 0 & 1 & 0 \\
\hline \multirow{2}{*}{$\begin{array}{l}\text { Family } 3 . \\
\text { trophonius : } \\
\text { escaped. }\end{array}$} & cenea & 4 & 1 & 0 & 0 \\
\hline & trophonius & 1 & 0 & - & - \\
\hline \multirow{3}{*}{$\begin{array}{l}\text { Family } 4 . \\
\text { hippocoon: } \\
\text { undivided. }\end{array}$} & cenea & 8 & 3 & $1 \frac{1}{2}$ & 0 \\
\hline & hippocoon & 3 & 1 & - & - \\
\hline & trophonius & 3 & 0 & - & - \\
\hline \multirow{2}{*}{$\begin{array}{c}\text { Family } 5 . \\
\text { cenea: divided. }\end{array}$} & cenea & 14 & 9 & 5 & 2 \\
\hline & hippocoon & 1 & 1 & - & 一 \\
\hline $\begin{array}{l}\text { Family } 6 . \\
\text { hippocoon: } \\
\text { undivided. }\end{array}$ & cenea & 13 & $3 \frac{1}{2} *$ & 2 & 1 \\
\hline
\end{tabular}

* Including No. 5 in which the spot is nearly divided.

A comparison of Family 5 with the others at once shows that there are certainly hereditary tendencies in details of the pattern. If the pattern of the model became more nearly approached by the division of spot (5) in the mimic, or by the addition of such elements as $(4 a)$ or $(2 \alpha)$, the above table supports the conclusion that selection would quickly confer these characters upon the cenea form of female. It is equally clear that these hereditary tendencies exist in the most varied combinations. Thus referring again to Plate XXIV, it is obvious that the addition of $(4 a)$ and $(2 a)$ tends to occur when the normal spots are well developed, but $(4 a)$ is present in Fig. 14, 
where they are small. So also with the submarginal spots which vary with but also independently of the chief spots (1)-(5). Thus the apical spot ( $\delta$ ) may be absent when (1)-(5) are small, as in Fig. 14, or when they are large, as in Fig. 19. But upon the whole it tends to be well developed when (1)-(5) are also well developed, as in Figs. 15-18, etc.

This kaleidoscopic combination of the various elements in a pattern, added to the existence of undoubted hereditary tendencies in the associations as well as in the individual components, enables us to understand how the complex detail of these mimetic patterns has been attained.

This most valuable and interesting material, which we owe to the skill and energy of Mr. G. F. Leigh, F.E.S., thus throws a flood of light upon two difficult and fascinating problems - the proportions of the mimetic forms to those of their particular models in each locality, and the more fundamental problem of the adjustment of the details of the mimetic patterns to those of the models.

\section{Explanation of Plates XXIII, XXIV.}

[See Explanation facing the Plates.] 


\section{$2 \mathrm{BHL}$ Biodiversity Heritage Library}

Leigh, G F and Poulton, Edward Bagnall. 1909. "XX. Heredity in six families of Papilio dardanus, Brown, Subspecies cenea, Stoll., bred at Durban, by." Transactions of the Entomological Society of London 56, 427-445. https://doi.org/10.1111/j.1365-2311.1909.tb02161.x.

View This Item Online: https://www.biodiversitylibrary.org/item/51068

DOI: https://doi.org/10.1111/j.1365-2311.1909.tb02161.x

Permalink: https://www.biodiversitylibrary.org/partpdf/26687

\section{Holding Institution}

Smithsonian Libraries

\section{Sponsored by}

Smithsonian

\section{Copyright \& Reuse}

Copyright Status: Public domain. The BHL considers that this work is no longer under copyright protection.

This document was created from content at the Biodiversity Heritage Library, the world's largest open access digital library for biodiversity literature and archives. Visit BHL at https://www.biodiversitylibrary.org. 